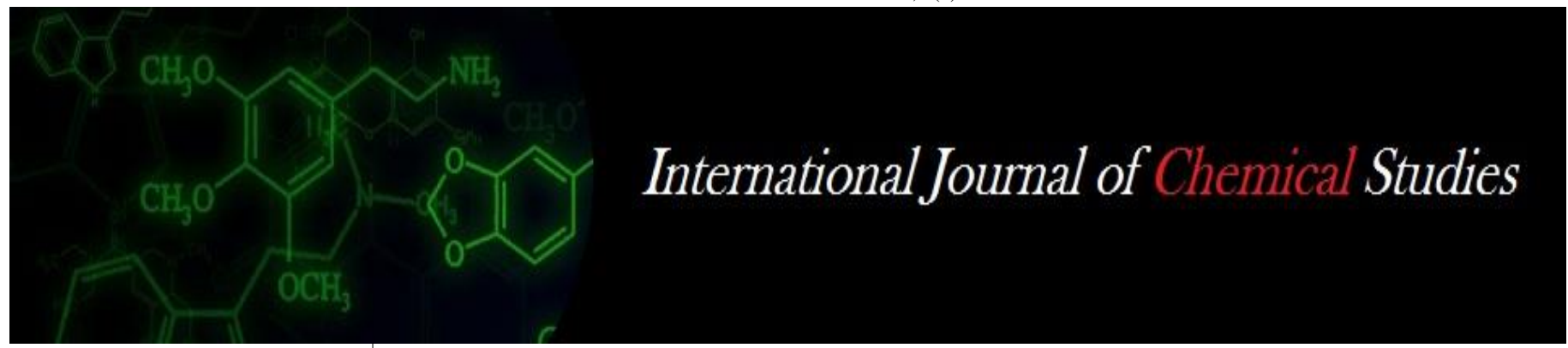

P-ISSN: 2349-8528

E-ISSN: 2321-4902

IJCS 2020; 8(1): 2552-2555

(C) 2020 IJCS

Received: 04-11-2019

Accepted: 06-12-2019

Diksha Sharma

Ph. D. Scholar, Swami

Keswanand Rajasthan

Agricultural University, Bikaner,

Rajasthan, India

BN Kalsariya

Associate Professor, Junagadh

Agricultural University,

Junagadh, Gujarat, India

Sonika Sharma

Research Scholar, Rajasthan

College of Agriculture, Udaipur,

Rajasthan, India

Devendra Kumar Meena

Assistant Professor, Department

of Extension Education, COA,

Bharatpur, Rajasthan, India
Corresponding Author:

Diksha Sharma

Ph. D. Scholar, Swami

Keswanand Rajasthan

Agricultural University, Bikaner,

Rajasthan, India

\section{Relationship between training needs of farm women and their selected independent variable about improved animal husbandry practices}

\author{
Diksha Sharma, BN Kalsariya, Sonika Sharma and Devendra Kumar \\ Meena
}

DOI: https://doi.org/10.22271/chemi.2020.v8.i1am.8650

\begin{abstract}
Animal husbandry is an integral component of Indian agriculture supporting livelihood of more than twothirds of the rural population. Many of the important tasks in animal husbandry are performed by women besides their responsibilities as home makers and caring of animals is considered as an extension of domestic activities. Keeping this in view, present study was thought to be taken out with measure the correlation between Socio-personal and socio-economic characteristics of farm women regarding improved animal husbandry practices studied in saurashtra region of Gujarat state, India because Saurashtra region has significant contribution of local cows (45\%) among the different region of state., the present investigation was conducted in Junagadh and Gir-somnath district of Saurashtra Region of Gujarat state was purposively selected. Two talukas selected from each selected districts for present study. Three villages were selected purposively from the each selected taluka having more population of cattle and buffalo, by selecting 10 from each selected village were taken by using random sampling technique with a condition that the farm women has been rearing animals on their farm at least 3 years or having herd, total 120 farm women were selected for research purpose. Out of fourteen independent variables, six variables viz. social participation, extension participation, mass media exposure, adoption, attitude and risk orientation had negative and highly significant correlation with training needs of farm women about improved animal husbandry practices. Education had negative and significant correlation whereas, age, size of family, dairy experience, size of land holding, herd size and economic motivation had non- significant association with training needs of farm women. Annual income was there that showed positive and significant correlation with training needs of farm women about improved animal husbandry practices. So, it can be concluded that those variables who had establish significant influence on training needs must be reckon while planning any training programme related animal husbandry practices.
\end{abstract}

Keywords: Animal husbandry, farm women, training needs, independent variable

\section{Introduction}

Animal husbandry is an integral component of Indian agriculture supporting livelihood of more than two-thirds of the rural population. Livestock contributed 16 per cent to the income of small farm households as against an average of 14 per cent for all rural households. It also provides employment to about 8.8 per cent of the population in India. The livestock sector alone contributes nearly 25.6 per cent of value of output at current prices of total value of output in agriculture, fishing \& forestry sector. The overall contribution of livestock sector in total GDP is nearly 4.11 per cent at current prices during 2012-13 ${ }^{[1]}$. Rural women are also responsible for collection, preparing dung cakes an activity that also brings additional income to poor families. Evidently, rural women are involved in almost all livestock related activities. In spite of active involvement of women in different animal husbandry activities, lack of exposure and assess to new technology has restricted women to show their full potential for the growth of livestock sector. In the process of transfer of technology, training of farmers, farm leaders and rural youth plays an important role. Farmer's training is a non-formal process of education which educates the farmers in a group on some specific topic at a particular place Shrivastva et al., (1996) ${ }^{[8]}$. So, by providing suitable need based training to the farmers we can improve their skills, leading to better adoption of new technologies. 
Moreover, the main problem of developing countries like India is not the lack of natural resources rather it is the underdeveloped human resource. So, training helps in acquiring the necessary skills among the livestock farmers, which in turn improves the productivity. Therefore, it becomes imperative to surface the required training needs among livestock owners.

\section{Research methodology}

The study was conducted in two district i.e. Junagadh and Gir somnath in south Saurashtra region of Gujarat. Purposive random sampling was used to for selection of respondents. Ex-post facto research design was followed. Interview schedule was prepared to study these parameters that was pretested and translated in Guajarati. The data of this study were collected through personal interview. Data were coded, classified, tabulated and analyzed using the software. The presentation of data was done to give pertinent, valid and reliable answer to the specific objectives. Frequencies, percentage, mean, standard deviation and Pearson product moment correlation coefficient $(r)$ were worked out for meaningful interpretation. For relationship between socioeconomic profiles of the respondents with perceived training needs, correlation coefficient (r) were computed and tested for their statistical significance.

\section{Result and Discussion Age and Training needs}

The data presented in the Table 1 revealed that age had negative and non-significant correlation (-0.08353) with training needs of farm women for improved animal husbandry practices. Thus, the null hypothesis ( $\mathrm{H} 01)$ that "there is no relationship between age of farm women and their training needs for improved animal husbandry practices" is accepted. Age of the respondent was not found to be significantly related with training needs of dairy farmers. The possible reason might be that, training need could be felt important depending upon the situation, need and knowledge of the respondent and not mostly upon the age. This finding is in line with findings reported by Kullayappa (2008) ${ }^{[2]}$, Patil $(2009)^{[4]}$.

\section{Education and Training needs}

The data reported in Table 1 reflects negative and significant correlation (-0.02021) between education and their training needs of farm women for improved animal husbandry practices. Thus, the null hypothesis $\left(\mathrm{H}_{0} 2\right)$ that "there is no relationship between education of farm women and their training needs for improved animal husbandry practices" is rejected.

It was noticed that, there is negative and significant relationship between education and training needs of the dairy farmers. It might be because education imparts knowledge and creates awareness and curiosity to learn skills and newer things. This result is supported by research carried out by Rajput (2010) ${ }^{[6]}$, Patel (2012) ${ }^{[3]}$.

\section{Size of family and Training needs}

The data presented in the Table 1 revealed that size of family had positive and non-significant correlation (0.0238) with training needs of farm women for improved animal husbandry practices. Thus, the null hypothesis $\left(\mathrm{H}_{0} 3\right)$ that "there is no relationship between size of family of farm women and their training needs for improved animal husbandry practices" is accepted.

This result indicates that irrespective of family size, farm women had different extent of training needs. It might be possible because family size does not intercept in expressing their training needs for improved animal husbandry practices. This finding is conformity with result illustrated by Patil (2009) ${ }^{[4]}$, Tekale (2013) ${ }^{[9]}$.

\section{Experience and Training needs}

It reflects from the data presented in the Table 1 that dairy experience has positive and non -significant correlation $(0.005519)$ with training needs of farm women for improved animal husbandry practices. Thus, the null hypothesis $\left(\mathrm{H}_{0} 4\right)$ that "there is no relationship between experience of farm women and their training needs for improved animal husbandry practices" is accepted.

This finding might be resulted from the fact that experience also increases the knowledge about different practices. This result is completely favoured by result showed by Kanwat and singh (2014) ${ }^{[1]}$.

\section{Size of land holding and Training needs}

It evident from the data presented in the Table 1 that size of land holding had negative and non-significant correlation (0.00606 ) with training needs of farm women improved animal husbandry practices. Thus, the null hypothesis $\left(\mathrm{H}_{0} 5\right)$ that "there is no relationship between size of land holding of farm women and their training needs about improved animal husbandry practices" is accepted.

This finding might be resulted from the fact that dairy management does not require larger quantity of produce which in turn fails to effect on training needs for different animal husbandry practices by farm women. This finding is supported by that of Patil (2009) ${ }^{[4]}$, Tekale (2013) ${ }^{[9]}$.

\section{Herd size and Training needs}

The data presented in Table 1 highlighted that herd size had positive and non-significant correlation (0.03562) with training needs of farm women about improved animal husbandry practices. Thus, the null hypothesis $\left(\mathrm{H}_{0} 6\right)$ that "there is no relationship between herd size of farm women and their training needs about improved animal husbandry practices" is accepted.

It can be concluded that herd size was found to be an independent factor with training needs because increase and decrease in hard size cannot affect the training needs of farm women. This finding is in conformity with the findings of Sharma (2011) ${ }^{[7]}$.

\section{Annual income and Training needs}

The data mentioned in the Table 1 reveal that annual income had positive and significant correlation (0.01842) with training needs of farm women improved animal husbandry practices. Therefore, the null hypothesis $\left(\mathrm{H}_{0} 7\right)$ that "there is no relationship between annual income of farm women and their training needs about improved animal husbandry practices" is rejected.

It is true that income decides persons spending. Farm women who have sufficient annual income can fulfil their basic requirement and interested to get training. This may be possible reason behind this finding. This finding is in line with that of Patel (2012) ${ }^{[3]}$, Kanwat and Singh (2014) ${ }^{[1]}$. 
Table 1: Relationship between training needs of farm women and selected independent variable $(n=120)$

\begin{tabular}{|c|c|c|}
\hline $\begin{array}{c}\text { S. } \\
\text { No }\end{array}$ & Independent variables & Correlation-coefficient ('r' value) \\
\hline 1 & Age & $-0.08353^{\mathrm{NS}}$ \\
\hline 2 & Education & $-0.2021^{*}$ \\
\hline 3 & Size of family & $0.0238^{\mathrm{NS}}$ \\
\hline 4 & Experience & $0.005519^{\mathrm{NS}}$ \\
\hline 5 & Size of land holding & $-0.00606^{\mathrm{NS}}$ \\
\hline 6 & Herd size & $0.03562^{\mathrm{NS}}$ \\
\hline 7 & Annual income & $0.01842^{*}$ \\
\hline 8 & Social participation & $-0.38262^{* *}$ \\
\hline 9 & Extension participation & $-0.46131^{* *}$ \\
\hline 10 & Mass media exposure & $-0.30973^{* *}$ \\
\hline 11 & Economic motivation & $0.024763^{\mathrm{NS}}$ \\
\hline 12 & Adoption & $-0.48264^{* *}$ \\
\hline 13 & Attitude & $-0.52941^{* *}$ \\
\hline 14 & Risk orientation & $-0.28781^{* *}$ \\
\hline
\end{tabular}

* Significant at 0.05 level $(\mathrm{r}=1.981)$

** Significant at 0.01 level $(\mathrm{r}=2.618)$

NS Non significant

\section{Social participation and Training needs}

The data presented in Table 1 illustrate that social participation had negative and highly significant correlation (0.38262 ) with training needs of farm women about improved animal husbandry practices. Thus, the null hypothesis $\left(\mathrm{H}_{0} 8\right)$ that "there is no relationship between social participation of farm women and training needs of farm women about improved animal husbandry practices." to be rejected.

The fact is that as social participation increases farm women came to know about new innovation regarding animal husbandry practices and they desired to adopt those technologies.

This finding is completely supported by findings reported by Rajput (2010) ${ }^{[6]}$.

\section{Extension participation and Training needs}

The perusal of data in Table 1 illustrate that extension participation had negative and highly significant correlation (0.04613 ) with training needs of farm women about improved animal husbandry practices. Thus, the null hypothesis $\left(\mathrm{H}_{0} 8\right)$ that "there is no relationship between extension participation of farm women and their training needs about improved animal husbandry practices" to be rejected.

The probable reason is that contact with extension functionaries make them aware about different practices like breeding, health care, improved animal breeds, loan facility and also about banking and insurance. This finding is in conformity with Rajput (2010) ${ }^{[6]}$, Sharma (2011) ${ }^{[7]}$.

\section{Mass media exposure and Training needs}

It is clear from data presented in Table 1 determine that mass media exposure had negative and highly significant correlation (-0.03097) with training needs of farm women about improved animal husbandry practices. This provides sufficient ground to reject the null hypothesis $\left(\mathrm{H}_{0} 9\right)$ that "there is no relationship between mass media exposure of farm women and their training needs about improved animal husbandry practices "is rejected.

It can be concluded that mass media exposure was found to be an important factor which played a vital role in increasing the knowledge level of the respondents regarding improved animal husbandry practices. The probable reason finding may be that the exposure through mass media provided the knowledge and understanding of improved practices in better way. This result is supported by Rajput $(2010)^{[6]}$.

\section{Economic motivation and Training needs}

It is apparent from the data presented in Table 1 that economic motivation had positive and non- significant correlation (0.02476) with training needs of farm women about improved animal husbandry practices. Thus, the null hypothesis $\left(\mathrm{H}_{0} 10\right)$ that "there is no relationship between economic motivation of farm women and their training needs about improved animal husbandry practices" is accepted. This result is completely in favoured by Punitha (2012) ${ }^{[5]}$.

\section{Adoption and Training needs}

The data showed in Table 1 indicate that adoption had negative and highly significant correlation (-0.48264) with training needs of farm women about improved animal husbandry practices. So, the null hypothesis $\left(\mathrm{H}_{0} 12\right)$ that "there is no relationship between adoption of farm women and their training needs about improved animal husbandry practices" is rejected.

\section{Attitude and Training needs}

It is apparent from the data presented in Table 1 that attitude had negative and highly significant correlation (-0.52941) with training needs of farm women about improved animal husbandry practices. Hence, the null hypothesis $\left(\mathrm{H}_{0} 13\right)$ that "there is no relationship between attitude of farm women and their training needs improved animal husbandry practices." is rejected.

\section{Risk orientation and Training needs}

The data presented in Table 1 illustrate that risk orientation had negative and highly significant correlation $(-0.2878)$ with training needs of farm women about improved animal husbandry practices. Thus, the null hypothesis $\left(\mathrm{H}_{0} 8\right)$ that "there is no relationship between risk orientation of farm women and training needs of farm women about improved animal husbandry practices." to be rejected.

This result obviously indicates that risk orientation played an important role in extent of training needs in dairy farming. Dairy farmers who have higher risk taking ability will obviously have the potential to adopt improve scientific practices. This might be the probable reason for the above finding. This finding is in conformity with that of Sharma $(2011)^{[7]}$.

\section{References}

1. Kanwat M, Singh P. Technological Needs of Farm Women in Dairy Farming: A Case of Udaipur District, Rajasthan. Indian Res. J Ext. Edu. 2014; 14(3):28-30.

2. Kullayappa KP, Prasad SV, Sastry TP. Training needs of groundnut farmers of Anantapur district of Andhra Pradesh. Current-Biotica. 2008; 2(1):41-55.

3. Patel AJ, Chaudhary MG, Patel JK. Awareness and technological needs of women in dairying. Guj. J Ext. Edu. 2012; 23:74-78.

4. Patil AP, Gawande SH, Nande MP, Gobade MR. Assessment of knowledge level of dairy farmers in Nagpur district and the co-relation between socioeconomic variables with their training needs. Veterinary World. 2009; 2(5):199-201.

5. Punitha P, Singh SB, Seetharaman RN. Gender differences on training needs among farmer's discussion groups. Indian Res. J Ext. Edu. 2012; 12(1):73-77. 
6. Rajput BPS. Training needs of dairy farmers for improved dairy farming practices in Bundelkhand region. M.V.Sc. (Ext.) Thesis (Unpublished) National Dairy Research Institute, Karnal, 2010.

7. Sharma K, Singh SP, Gautam. Personal Attributes Affecting Training Needs Perception of Buffalo Farmers. Indian Res. J Ext. Edu. 2011; 11(1):57-61.

8. Shrivastava KK, Bareth SL, Sarkar JD. Impact of farmers training centre on farmer community. Agricultural Extension Review. 1996; 8(5):23-24.

9. Tekale M, Deshmukh DS, Rathod PK, Sawant M. Training Needs of Goat Keepers in Maharashtra. Indian Res. J Ext. Edu. 2013; 13(2):67-71. 